\title{
Protecting the Rights of Children in Conflict with the Law: Children's Constitutional Rights Perspective
}

\begin{abstract}
Wahdah Zainal Imam
Faculty of Law, Khairun University, North Maluku, Indonesia

Abstract

Violence against women is one of the crucial social mechanisms that encourage women in a position of subordination compared to men. In many cases even law enforcement officers and the community tend to see this type of violence as the fault of women themselves and also the myths that accompany it. The research is a legal research using a case and conceptual approaches. The results show that the punishment for children against with law as sexual crime perpetrator must not ignore the aspect of development as a broader social planning strategy. Legal protection and rights for children are one of the approaches to protect children in order to grow and develop properly, especially children in Indonesia. As a systemic process, the criminal law enforcement emerges as a criminal law application which involves various structural sub-systems such as police, prosecutors, courts and also correctional institutions. Above all, the 1945 Constitution as the highest law expressly held that children have constitutional rights.
\end{abstract}

Keywords: Children; Constitutional Right; Human Right; Sexual Crime

DOI: $10.7176 / J L P G / 92-23$

Publication date: December $31^{\text {st }} 2019$

\section{Introduction}

For almost two centuries, children were largely absent from the class of constitutional rights-holders. ${ }^{1}$ From criminological perspective, violence in the community are not something new, violence is often performed together with a crime. The crime is performed with violence or threat of violence, while ways and tools to do violence are each depends on the cases as arise, it is casuistic in nature that each of action can combat anyone, both men and women, from children to adulthood. ${ }^{2}$ Even tough, the theory that children do not possess adult rights because they lack autonomous decision making skills is reinforced by the existence of a robust constitutional doctrine of parental rights. ${ }^{3}$

Recently, violence in the community seems to be increasing in both quality and quantity. The type of violence many comes from cultural factors that place women in vulnerable positions than men. This is recognized by the international community as stated in the UNs Declaration on the Elimination of Violence against Women (hereinafter referred to as the Declaration on the Elimination of Violence). It causes the emergence of domination and discrimination against women by men so that it would be an obstacle to their progress. Violence against women is one of the crucial social mechanisms that encourage women in a position of subordination compared to men.

Balancing these factors raises a number of hard questions. ${ }^{4}$ For example, at what age should children be held criminally responsible for their actions, what is the correct role of welfare assistance in the process, and to what extent should state power to deal with child offending be transferred to families, victims, and communities?

Meanwhile, our national legal system both in terms of substance, attitudes of the law enforcers as well as the community still consider violence against women is equal to the general crimes. Therefore, the type of crime is treated same as other crime (classified as general crime). In many cases even law enforcement officers and the community tend to see this type of violence as the fault of women themselves and also the myths that accompany it.

To understand the meaning of children is needed a special attention not only in the body of knowledge, but it can be examined from the perspective of the centralization of life such as religion, law and sociology that makes the meaning of children is more rational and actual in a social environment. In this regard, the presence of the

\footnotetext{
${ }^{1}$ Dailey, Anne C. "Children's Constitutional Rights." Minnesota Law Review. 95 (2010): 2099-2179.

${ }^{2}$ Rukmini Sen, 2010, Women's Subjectivities of Suffering and Legal Rhetoric on Domestic Violence : Fissures in the two Discourses, SAGE Publications, New Delhi, h. 390.

${ }^{3}$ Dailey, Anne C. Loc. Cit.

${ }^{4}$ Becroft, A. J. (2006). Children and young people in conflict with the law: Asking the hard questions. Juvenile and Family Court Journal, 57(4), 1-37.
} 
internet has opened new horizons in human life. It brings progress to the created new space or world called cyberspace, it is a world of computer-based communication.

The development of technology is one of the factors that can lead to crime, while the crime itself has existed and emerged from the beginning of the era until now and in the future. Forms of crime that are existed increasingly varied such as data theft, copyright violations including human trafficking for sexual exploitation. Thus, the increase of recorded sexual crimes it will also increase trafficking crimes.

Romli Atmasasmita argued that many parents slip by negatively influencing the development of children lives. ${ }^{1}$ In a separate note from throughout 2017 , there were 179 cases of violence against children. It is well-understood that not only does the Indonesian Constitution expressly and clearly protect human rights and against discrimination, but incidents with various modes of operation cause victims to suffer, they become stressed, depressed, scared, traumatized, and afraid to meet the perpetrator, and defect physically.

\section{A Causative Review for Child in Constitutional Perspective}

The development of computer technology led to the emergence of types of crime in the world of internet such as commercial sexual exploitation against children through internet media. The crime of exploitation against children is increasingly prevalent through internet media with various modes including sexual exploitation of children.

Speaking of law in Indonesia, there is no law in force in Indonesia that recognizes student problems. In a legal perspective, students are well-known as children. In the Indonesian's dictionary, the child is given a meaning as follows:

a) The second offspring;

b) Humans are still small;

c) People who come from or born (foreign or domestic), for people included in the occupational group (family and so on).

The limitation of someone is still said to be a child is used to designate a situation where someone in the law is deemed unable to take responsibility for legal actions he/she does. In ordinary peoples, adults are known for signs of maturity that appear in children such as having a wet dream, and it usually things that indicate the maturity of children appear around the age of 12 years for sons and 9 years for girls. Based on the result of the research, data on crimes committed in general by children under-age and handled by the Attorney Office in Southeast Sulawesi Province can be collected.

Based on Act No. 11 of 2012 concerning the Juvenile Justice System regulates the roles and duties of the community, government, and other institutions that have the obligation and responsibility to improve the welfare and special protection of children against the law.

The object of the juvenile justice is child, although in the juvenile justice it is not merely coincide with the child. There are other things as part that coincides with children and it is inseparable because they are the motor and driving-force of juvenile justice, both related to infrastructure and especially human resources. ${ }^{2}$

Indonesia already has specific legislation that regulates the development and protection of children as perpetrators of child crime, especially in its judicial process, including Act No. 8 of 1981 concerning the Criminal Procedure Code and Act No. 11 of 2012 concerning the Juvenile Criminal Justice System. Act No. 23 of 2002 concerning Child Protection, Act No. 12 of 1995 concerning Penitentiary, and Presidential Decree of the Republic of Indonesia No. 36 of 1990 concerning Ratification of the Convention on the Rights of the Child. ${ }^{3}$ To date in Indonesia the use of the term child is still pluralistic and there is no clear unification of this. The child is said to be an adult in customary law when he is strong, which means he can take care of himself and his assets and is capable of doing all the social intercourse.

As results of the research, the author concludes that the causing factors the students to commit crimes, especially persecution are: the first, unharmonious parents/family environment. Family especially the parents become a factor that can cause children to commit crimes. Children feel unimportant in the family, so children are more likely to do negative things to get their parent's attention, and express their frustration and disappointment. In

\footnotetext{
${ }^{1}$ Atmasasmita, R. Problema Kenakalan Anak-anak dan Remaja, Bandung; Armico, 1986, p.11.

${ }^{2}$ Loc. Cit.

${ }^{3}$ Komariah, Tinuk Dwi Cahyani, "Efektifitas Konsep Diversi Dalam Proses Peradilan Anak Pelaku Tindak Pidana Menurut UU No. 11 Tahun 2012 Tentang Sistem Peradilan Pidana Anak (Dalam Proses Peradilan Anak Pelaku Tindak Pidana Di Kabupaten Malang)." The Scientific Journal of Legality Law, Edition No.2 Vol.24, Universitas Muhammadiyah Malang, September 2016 - February 2017, p. 267.
} 
traditional communities, in the family life between parents and children lives in a harmonious culture, not many external influences arise and as a result a stable and harmonious atmosphere is created without experiencing difficulties in solving a problem.

In contrast to modern communities, they are filled with various activities for the needs of their family. It takes up a lot of time for parent, so the time to take care of children is taken up by it. If this happens it is difficult for children to express and complain about the problem. Thus, it will make children become frustrated because there is no more place to convey the problems they face.

Lack of parents' sensitivity to understand the problems and needs their children and communication will make children to find their own way in order to do all their desires. Ultimately, the parents unconsciously see their children have done actions that lead to deviant forms of behavior. In addition, the lack of parental supervision of children can also result in children acting outside the norms and regulations.

The second is association or child community. Also, this factor has large influence in creating mental children who always want to do evil. As social creatures, humans always want to live in groups. Also, sometimes in a wrong association, friends invite to commit crimes, children who are basically still unstable, can easily be influenced by their friends. Environmental factors have a major influence in the formation of character, because the values around them will affect the development of their soul.Identity crisis causes they cannot learn and differentiate right and wrong behavior and they tend behave naughty. Likewise, for those who already know the difference of behavior, but they cannot develop self-control to behave according to their knowledge. For examples, peoples who always hide problems and not open.

Legal understanding is an understanding for certain behaviors that are regulated by law. ${ }^{1}$ Certainly, the legal language referred to here is written and unwritten laws. Such knowledge or understanding is related to behavior that is prohibited or permitted by law. Legal understanding as referred here is amount of information owned by person about the contents of the rules of a particular law. The attitude of the law is a tendency to accept the law because the respecting of the law as something beneficial if the law is obeyed. Legal behavior and the pattern of legal behavior is the main thing in legal awareness because here it can be seen whether a regulation applies or not in community.

\section{Attempt to Overcome the Sexual Crimes Committed by Children}

Children as a gift created by God Almighty and as a social being from the womb, they have the right to live and be independent and get protection. Reviewing from the juridical aspect, the understanding of children in the eyes of positive law in Indonesia is commonly interpreted as a person who is not yet an adult (minderjarig/person under age), under-age (minderjarigheid/inferiority) or often also referred to as a child under the supervision of a guardian (minderjarig ondervoordij). ${ }^{2}$

The substance of this indicates that positive $\operatorname{law}^{3}$ in Indonesia does not recognize legal unification which is standard, imperative, and universally applies to the technical terminological uniformity of the understanding of child and does not determine the age limit criteria for a child. Meanwhile, the understanding of child as regulated in statutory regulations is different from those stipulated in customary and Islamic laws. International law also regulates the definition of children, as stipulated in the UNs Convention on the Rights of the Child in 1989, United Nations Standard Minimum Rules for the Administration of Juvenile Justice (The Beijing Rules) in 1985 and the Universal Declaration of Human Rights in $1948 .{ }^{4}$

The consideration of the judge is the reason for ruling a decision. It is a most important aspect in determining the realization of the value of a judge's decision that contains justice (ex aequo et bono) and contains legal certainty, in addition it also contains benefits for the parties concerned so that the consideration of the judge must be addressed carefully, well, and accurate. If the considerations of the judge are not careful, good, and accurate, then the judge's decision that comes from the consideration will be canceled by the High Court or Supreme Court.

\footnotetext{
${ }^{1}$ Alamsari, S. Heny., Irwansyah, Muhadar, Heryani, W. 2019. Law Enforcement of Money Laundering: Case Studies on Fighting Narcotic Crime, Journal of Law, Policy and Globalization, Vol. 88, 12.

${ }^{2}$ Niken Savitri, 2008, HAM Perempuan, Kritik Teori Hukum Feminis terhadap KUHP, Refika Aditama Press, Bandung, p. 2.

${ }^{3}$ Sofyan, Andi and Asis, A. (2013). Hukum Acara Pidana, Suatu Pengantar, Kencana, Jakarta.

${ }^{4}$ Pusat Kajian Wanita dan Gender UI, 2004, Hak Azasi Perempuan Instrumen Hukum untuk Mewujudkan Keadilan Gender, Yayasan Obor Indonesia, Jakar., p. 33
} 
Repressive measures are attempts conducted by law enforcers, in the form of sentencing or criminal sanctions to perpetrators, in this case performed by the police, prosecutors and courts. In addition to preventive measures that can be taken by the police. The police can also take repressive measures. Repressive actions taken must be in accordance with established procedures and on orders from the highest superiors in the regional police.

As a systemic process, criminal law enforcement emerges as criminal law application which involves various structural sub-systems such as police, prosecutors, courts and correctional institutions (penitentiary) and certainly includes legal advisory institutions. In this case, law application must be viewed from 3 (three) dimensions, namely: the first, law application is viewed as a normative system; the application of all rule of law that describes social values supported by criminal sanctions; the second, law application is viewed as an administrative system which includes interactions between various law enforcement apparatuses which constitute the judicial sub-system; the third, criminal law application is a social system, in the sense that in defining criminal offense must also be taken into account various perspectives that exist in the communities. In relation with the various dimensions above it can be said that the actual results of the criminal law application must describe the overall results of the interaction between law, administrative practice and social actors.

So, part of a systemic process is a penal policy, its operationalization through several stages, namely the formulation stage (legislative policy), the application stage (judicial policy) and the execution stage (execution/administration policy). Of the three stages, the formulation stage is the most strategic stage of crime prevention efforts through penal policy. Disadvantageous of legislative policy are strategic mistakes that can be obstacles to efforts to prevent and deal with crime at the application and execution stages. ${ }^{1}$

Therefore, it can be said that a criminal politics using a penal policy must be an effort or stages that are made deliberately and consciously in choosing and establishing criminal law as a means to deal with crime must really have taken into account all the factors that can support the functioning or operation of criminal law in reality. Hence, it also requires a functional approach and as an inherent approach in every rational policy.

\section{Conclusion}

Punishment for children against with law as sexual crime perpetrator must not ignore the aspect of development as a broader social planning strategy. Legal protection and rights for children are one of the approaches to protect children in order to grow and develop properly, especially children in Indonesia. Children's right protection can be conducted in a regularly, orderly, and responsible manner so that legal regulations that are in line with the development of Indonesian peoples are fully spirited with Pancasila and the 1945 Constitution. Therefore, as a systemic process, the criminal law enforcement emerges as a criminal law application which involves various structural sub-systems such as police, prosecutors, courts and correctional institutions (penitentiary) and also includes legal advisory institutions.

Obstacles faced in the application of child crime as sexual crime perpetrator are multidimensional experienced by families, among others unstable economic life, problems at work, household to disharmony relationships within the family. Violence act against children are often not easily revealed, because violence against children, especially within the family is personal. Also, it is supported by the public perception that the problems that occur within the family are internal problems and are not suitable for interference. This attitude raises the silence attitude or passivity of the community around children, so that the violence against children continues and causing the survival of children.

\section{References}

Anne C. Dailey. (2010). "Children's Constitutional Rights." Minnesota Law Review. 95: 2099-2179.

Alamsari, S. Heny., Irwansyah, Muhadar, Heryani, W. (2019). Law Enforcement of Money Laundering: Case Studies on Fighting Narcotic Crime, Journal of Law, Policy and Globalization, Vol. 88, 12.

Becroft, A. J. (2006). Children and young people in conflict with the law: Asking the hard questions. Juvenile and Family Court Journal, 57(4), 1-37.

Fitriyah Ingratubun, H. M. Said Karim, Marthen Arie, Iin Karita Shakharina. (2018). Responsive Legal Protection Against Child Abduction: A Human Rights Perspective, Journal of Law, Policy and

\footnotetext{
${ }^{1}$ Fitriyah Ingratubun, H. M. Said Karim, Marthen Arie, Iin Karita Shakharina. 2018. Responsive Legal Protection Against Child Abduction: A Human Rights Perspective, Journal of Law, Policy and Globalization, Vol. 71, p. 91.
} 
Globalization, Vol. 71, p. 91.

Komariah, Tinuk Dwi Cahyani, (2017). "Efektivitas Konsep Diversi Dalam Proses Peradilan Anak Pelaku Tindak Pidana Menurut UU No. 11 Tahun 2012 Tentang Sistem Peradilan Pidana Anak," The Scientific Journal of Legality Law, Edition No.2 Vol.24, p. 267.

Marzuki, Peter Mahmud, (2005), Penelitian Hukum, Prenada Media, Jakarta.

Niken, Savitri, (2008), HAM Perempuan, Kritik Teori Hukum Feminis terhadap KUHP, Refika Aditama Press, Bandung.

Pusat Kajian Wanita and Gender UI, (2004), Hak Asasi Perempuan Instrumen Hukum untuk Mewujudkan Keadilan Gender, Yayasan Obor Indonesia, Jakarta.

Romli Atmasasmita. (1986). Problema Kenakalan Anak-anak dan Remaja, Bandung; Armico.

Rukmini Sen, (2010), Women's Subjectivities of Suffering and Legal Rhetoric on Domestic Violence: Fissures in the two Discourses, SAGE Publications, New Delhi.

Sofyan, Andi and Asis, A. (2013). Hukum Acara Pidana, Suatu Pengantar, Kencana, Jakarta. 